\title{
Border Identity Politics: The New Mestiza in Borderlands
}

Lamia Khalil Hammad

Yarmouk University, Irbid-Jordan

\begin{abstract}
This paper investigates Anzaldua's Borderlands, first, for its radical theory of the mestiza consciousness and how it would establish the border identity for the Chicana/o people.Anzaldua's Borderlands exemplifies the articulation between the contemporary awareness that 'all' identity is constructed across difference and argues for the necessity of a new politics of difference to accompany this new sense of self. Borderlands maps a sense of the plurality of self, which Anzaldua calls mestiza or border consciousness. This consciousness emerges from a subjectivity structured by multiple determinants-gender, class, sexuality - in competing cultures and racial identities.
\end{abstract}

[Keywords: Anzaldua, Border, Identity, Politics, Mestiza.]

The writing of women of color is crucial in the project of minority categorical expansion, which marginalizes some women while others become more valued, producing what Cherrie Moraga calls "theory of flesh" (Moraga and Anzaldua, Bridge 23). This embodied theory emerges from the material reality of multiple oppressions and in turn conceptualizes that materiality. The embodied subjectivities produced in the texts of women of color allow for an understanding of "gendered racial identities" or "racialized gender identities" (Gordon 105). For this reason, Hall proposes the possibility of another kind of "politics of difference". New political identities can be formed by insisting on difference that is concretely as "the factor that every identity is placed, positioned, in a culture, a language, a history". This conception of the self allows the self for a politics that constitutes "unities-in-difference"(45), a politics of articulation, in which the connections between individuals and groups do not arise from "natural" identity but must be articulated, in the dual sense of "expressed in speech" and "united by forming a joint"(45). This paper tends to investigate Anzaldua's Borderlands, first, for its radical theory of the mestiza consciousness and how it would establish the border identity for the Chicana/o people.

Anzaldua's Borderlands exemplifies the articulation between the contemporary awareness that 'all' identity is constructed across difference and argues for the necessity of a new politics of difference to accompany this new sense of self. Borderlands maps a sense of "the plurality of self" (Alarcon, 366), which Anzaldua calls mestiza or border consciousness. This consciousness emerges from a subjectivity structured by multiple determinants-gender, class, sexuality-in competing cultures and racial identities.

Sandoval has theorized a political identity that allows no single conceptualization of our position in society as a skill developed by those

Rupkatha Journal on Interdisciplinary Studies in Humanities (ISSN 0975-2935), Vol 2, No 3, 2010

URL of the Issue: http://rupkatha.com/v2n3.php

URL of the article: http://rupkatha.com/V2/n3/BorderldentityPolitics.pdf

(c) www.rupkatha.com 
marginalized in the categories of race, sex, or class for reading the shifting of the webs of power (66-67). She sees the term "women of color" not as a single unity but as a conscious strategy, a new kind community based on the strength of diversities as the source of a new kind of political movement. Sandoval's theory legitimates the multiplicity of tactical responses to the transferable circulation of power and meaning and posits a new, shifting subjectivity capable of reconfiguring and recentering itself, depending on the forms of oppression to be confronted. Anzaldua enacts this consciousness in Borderlands as a constantly shifting process or activity of breaking down binary dualism and creating the third space, the in-between, border, or interstice that allows contradictions to co-exist in the production of the new element (mestizaje, or hybridity). Crucial in her project are the ways "race" works in the complex "interdefining" and "interacting" among the various aspects of her identity (King 86).

Anzaldua, who as a Chicana lesbian of working-class origins enjoys no privilege in the categories of race, culture, gender, class, or sexuality, explicitly articulates her project; "belonging" nowhere, since some aspect of her multiple identity always prohibits her from feeling completely "at home" in any one of the many communities in which she holds membership; she will create her own "home" through writing:

I want the freedom to carve and chisel my own face,... to fashion my own gods out of my entrails. And if going home is denied me then I will have to stand and claim my space, making a new culture-una cultura mestiza- with my own lumber, my bricks and mortar and my own feminist architecture. (22)

Mestiza consciousness is not a given but must be produced, or built (lumber, bricks and mortar, and architecture); it is spatialized, "a piece of ground to sand on" (23), racialized "mestiza", and presented as a new mythology, a new culture, a non-dualistic perception and practice" "The future depends on the straddling of two or more cultures. By creating a new mythos - that is, in the way we perceive reality, the way we see ourselves, and the way we behave-la mestiza creates a new consciousness" (80).

In Borderlands, this new consciousness is created through writing: Anzaldua's project is one of discursive self-formation. Through writing she constructs a consciousness of difference, not in adversarial relation to the "same" but as what Alarcon calls the "site of multiple voicings" (365). The evocation of essentialism in the text is in service of a constructionist project, the production of a border or mestiza consciousness that gives voice and substance rendered mute and invisible by hegemonic practices and discourses, and is understood as the necessary prelude to political change (Anzaldua 87).

Borderlands' emphasis on the elaboration of a consciousness that emerges from an awareness of multiple subjectivity not only contributes to the development of a new paradigm for the theorizing differences, but also addresses aspects of identity formation for which theories of subjectivity alone 
are unable to account. Anzaldua's construction of mestiza consciousness helps us begin to distinguish between subjectivity and consciousness:

Subjective aspects of struggle ... [that] moment in subjective flux when social subjects... Produce accounts of who they are, as conscious political agents, that is, constitutes themselves, politically... Subjects are contradictory, "in process", fragmented, produced. But human beings and social movements also strive to produce some coherence and continuity, and through this, exercise some control over feelings, conditions and destinies. (69)

It is apparent that readings of Anzaldua's text, for different reasons, could emphasize either the positivity or negativity of 'living in the borderlands'. What strikes me most is the emphasis she places on the work involved in transforming the pain and isolation of 'in-between-ness' into an experience of empowerment through the construction of mestiza consciousness in writing (73). Anzaldua describes the paralyzing tensions of her multiple positionings:

Alienated from her mother culture, 'alien' in the dominant culture, the woman of color does not feel safe within the inner life of her Self. Petrified, she can's respond, her face caught between los intersticios, the spaces between the different worlds she inhabits. (20)

Borderlands is marked by such contradictory movements: the pain and strength of living in the borderlands, a preoccupation with the "deep...underlying structure" and the affirmation that "the bones often do not exist prior to the flesh" (66), la facultad as both a dormant "sixth sense" and a "survival tactic" developed by the marginalized (38-39). Since, as Mohanty points out, the "uprooting of dualistic thinking... is fundamentally based on knowledges which are often contradictory", mestiza consciousness involves "negotiating these knowledges, not just taking a simple counterstance" (Mohanty 36-7). This articulation of Anzaldua's project challenges the Western philosophical tradition based on binary oppositions and its own textual workings, given the tension between mestiza consciousness as an activity or process of the non-unitary subject and the crystallized production of the "name" mestiza consciousness in Borderlands.

Borderlands juxtaposes essays and poetry, political theory and cultural practice, not separating one from the other but producing a fusion of the two, a "theory in the flesh". The writing of Anzaldua gives theory a new face. She struggles to make sense of what it means to be working-class Chicana lesbian in essays that are collages of dreams, journal entries, poems, and autobiographical reflection. Anzaldua herself characterizes Borderlands "mosaic" or "weaving pattern" as writing that threatens to "spill over the boundaries", that offer a "hybridization of metaphor... full of variations and seeming contradictions", that refuse the neat dichotomy of "deep structure" and "smooth surfaces" in its "central core, now appearing, now disappearing in a crazy dance" (66). 
In the first essay, entitled "Homeland", Anzaldua addresses the history of the border between the United States and Mexico. "Homeland" establishes the original presence of the Indians on the land" "This land was Mexican once, / was Indian always / and is. / and will be again" 3), and introduces the notion of mestizaje in racial terms-the product of the sexual union of Spaniard and Indian. This essay traces the successive waves of conquest and domination of the land and its peoples by Spain, Mexico, and the United States, including the systematic lynching of Mexicans by Anglo settlers. Anzaldua refers to the border as a "1,950 mile-long open wound/ dividing a pueblo, a culture,/ running down the length of my body, staking rods in my flesh,/ splits me splits me" (2). This initial image figures the border as the writing subject's own body, exemplifying Anzaldua's embodied theory and subjectivity.

After having established the border and racial and cultural mestizaje as "Homeland", Anzaldua problematizes the concept of "home" in the second essay, "Movimientos de rebeldia y las culturas que traicionan". Paradoxically, she must leave home to find home (16). In this essay, she records her rebellion against her culture's betrayal of women. She demands an accounting from all three cultures. (White, Mexican, and Indian) of what has been oppressed in each. In Anzaldua's case, "being home" depends on the exclusion of women and specifically the dark-skinned Indian self she had to repress to remain within the safe boundaries of "home". The two sections, "How to Tame a Wild Tongue" and "Tlilli Tlapalli: the Path of the Red and Black Ink", deal with language and writing, the tools for the discursive production of mestiza consciousness. In "How to Tame a Wild Tongue", Anzaldua records both her refusal to remain silent (the wild tongue cannot be tamed, only cut out) and the ways in which her language is not "appropriate" according to dominants norms (54). Anzaldua is both inappropriate according to the dominant norm and inappropriated by it. She writes of the "linguistic terrorism" experienced by Chicanos whose language inhabits the border between Mexico and the United States. The tradition of silence has been imposed not just by the dominant English speaking culture (punished for speaking Spanish at school, criticized by Mexican relatives for speaking English with an accent) but also by "standard" Spanish speakers of Spain and Latin America. These two essays confect yet another kind of mestizaje informing the border consciousness: linguistic mestizaje, the language of the border that transgresses the boundaries between Spanish and English, high and low decorum, insider and outsider speech. Anzaldua claims her language as another kind of homeland (55) and as a part that mediates the binary split to construct the third element.

In "The Path of the Red and Black Ink", writing for Anzaldua is not so much an analytical activity as shamanistic process of transformation (66). Anzaldua uses the nahual notion of writing as creating face, heart, and soul to explore the idea that it is only through the body that the soul can be transformed. Trinh makes the distinction between writing yourself (writing the body), and writing about yourself. The second reinscribes the Priest/God 
standpoint of the all-knowing subject; "the first refers to a scriptive act-the emergence of a writing self" (28). Although the two overlap in Borderlands, it is the first that Anzaldua described as crucial to her new mythology and to her project of rupturing the dualism opposing body and soul, writing and the body. Here, Anzaldua contextualizes the Coatlicue state in the activity of writing: "Blocks 'Coatlicue states' are related to my cultural identity... the stress of living with cultural ambiguity both compels me to write and blocks me" (74). To the signifiers of "mestiza" and "queer" as border crossers, Anzaldua adds: "Being a writer feels very much like being a Chicana, or being queer" (72). All, through "shifts"- cultural, racial, gender, and linguist5ic shifts- "reprogram consciousness", the writer "through words, images, and the body sensations" (70).

The final essay constructs the "new mestiza" as the point of confluence of conflicting subject positions: "This assembly is not one where severed or separated pieces merely come together. Nor it is a balancing of opposing powers. In attempting to work out a synthesis, the self has added a third element which is greater than the sum of its severed parts" (79-80). The cultural practice of the new mestiza is a political practice possible by the achievement of awareness and acceptance of the plural self (87). In its emphasis on the inner struggle, this essay provokes thought on the relationship between individual transformation and social change (87). As Hall suggests, this new conception of the non-unitary self, or mestiza consciousness, allows for a politics of articulation, not of essential unity or correspondence, but of "unities-in-difference". In this spirit, Anzaldua proposes coalition with men, particularly Mexican/Chicano men, who are willing to become anti-sexist, to learn the Virgin/ Malinche duality and to put Coalticue back in Guadalupe, and with white people of both sexes who are willing to become anti-racist-to learn all peoples' histories of oppression and resistance.

An interesting correlation is that the more radical the form and content is, the greater the self-affirmation is. As Anzaldua is strikingly radical in her own theory of a new mestiza consciousness and in breaking the binary opposition to create a third "in-between-consciousness".

\section{Works Cited}

Alarcon, Norma. "The Theoretical Subject(s) of This Bridge Called My Back and AngloAmerican Feminism." Anzaldúa. Making Face. 356-69.

Anzaldúa, Gloria. Borderlands/ La Frontera: The New Mestiza. San Francisco: Spinsters/Aunt Lute, 1987.

Anzaldúa, Gloria. (Ed.) Making Face, Making Soul/ Haciendo Caras: Creative and Critical Perspectives by Women of Color. San Francisco: Aunt Lute, 1990.

Gordon, Linda."On Difference." Genders. 10, (Spring 1991): 91-111.

Hall, Stuart."Minimal Selves." Identity. Ed. Lisa Appignanesi. London: ICA Document 6, 1987. King, Katie. Producing Sexes, Theory, and Culture. New York: Routledge \& Paul, 1990. Mohanty, Chandra. "Introduction: Cartographies of Struggle." Third World Women and the 
Politics of Feminism. Ed. Chandra Mohanty, Ann Russo, and Lourdes Torres.

Bloomington: Indiana UP, 1991.

Moraga, Cherrie, and Gloria Anzaldua, eds. This Bridge Called My Back: Writings by Radical Women of Color. New York: Kitchen Table, 1983.

Sandoval, Chela. "Feminism and Racism: A Report on the 1981 National Women's Studies Association Conference." Anzaldúa, Making Face 1990. 55-71.

Trinh, Minh-ha. "She, the Inappropriate/d Other." Discourse 8, 1987.

Lamia Khalil Hammad is an Assistant Professor of American Literature and Women's Studies at Yarmouk University, Jordan.

Email:Ikhammad@yu.edu.jo 